The Editor,

Fournal of Glaciology

SIR,

\section{Age of Himalayan bottom ice cores}

Dating of tropical and Equatorial ice cores drilled in high mountain glaciers is difficult because seasonal variations can be traced only in the upper part. Modelling of the ice flow is difficult at depth due to the rapid thinning of the ice layers. Fortunately, atmospheric trace gases whose lifetime exceeds the inter-hemispheric mixing time $(\sim$ lyear $)$ are tracers on a global scale. By combining several gases, it is possible to attribute the age of an unknown ice layer by comparison with other well-dated ice-core records (Chappellaz and others, 1997a; Landais and others, 2003). Methane and the isotopic composition of atmospheric $\mathrm{O}_{2}\left(\delta^{18} \mathrm{O}_{\text {atm }}\right)$ are preferentially used for such purposes because of their suitable atmospheric turnover time $\left(\sim 10\right.$ years for $\mathrm{CH}_{4}$ and $\sim 1500$ years for atmospheric $\mathrm{O}_{2}$ ).

We recovered one ice core to bedrock (117.06 m long) in 2001, and two more, also to bedrock, (108.83 and $95.80 \mathrm{~m}$ ) in 2002 on the col of East Rongbuk Glacier $\left(28^{\circ} 01^{\prime} \mathrm{N}, 86^{\circ} 58^{\prime} \mathrm{E}\right.$; $6518 \mathrm{~m}$ a.s.l.) on the north slope of Qomolangma (Mount Everest) (Fig. 1). Hereafter we refer to the $117.06 \mathrm{~m}$ core as "core 2001", and the 108.83 m core as "core 2002". East Rongbuk Glacier covers an area of $48 \mathrm{~km}^{2}$ with a length of $14 \mathrm{~km}$. Borehole temperatures at the $108.83 \mathrm{~m}$ core site range from $-8.9^{\circ} \mathrm{C}$ at $10 \mathrm{~m}$ to a minimum of $-9.6^{\circ} \mathrm{C}$ at $20 \mathrm{~m}$, then increase slightly to $-8.9^{\circ} \mathrm{C}$ at the bottom. Measurements of $\delta^{18} \mathrm{O}_{\text {atm }}$ and methane were performed at the Laboratoire des Sciences du Climat et de l'Environnement (LSCE) and the Laboratoire de Glaciologie et Géophysique de l'Environnement (LGGE) respectively. Details of the measurements are available elsewhere (Chappellaz and others, 1997b; Landais and others, 2003).

The narrow range of our $\delta^{18} \mathrm{O}_{\text {atm }}$ results $(-0.09 \%$ to $0.26 \%$ ) with respect to the Greenland Ice Sheet Project 2 (GISP2) ice core (Fig. 2; note the different vertical scales) suggests no glacial origin of the bottom ice. But we cannot decipher whether the bottom ice originated from the early or late Holocene, because the narrow $\delta^{18} \mathrm{O}_{\text {atm }}$ band of our cores runs across the GISP2 $\delta^{18} \mathrm{O}_{\text {atm }}$ profile during these two periods. If early-Holocene, the age of core 2001 at $102.5 \mathrm{~m}$ depth or of core 2002 at $87.5 \mathrm{~m}$ depth should be

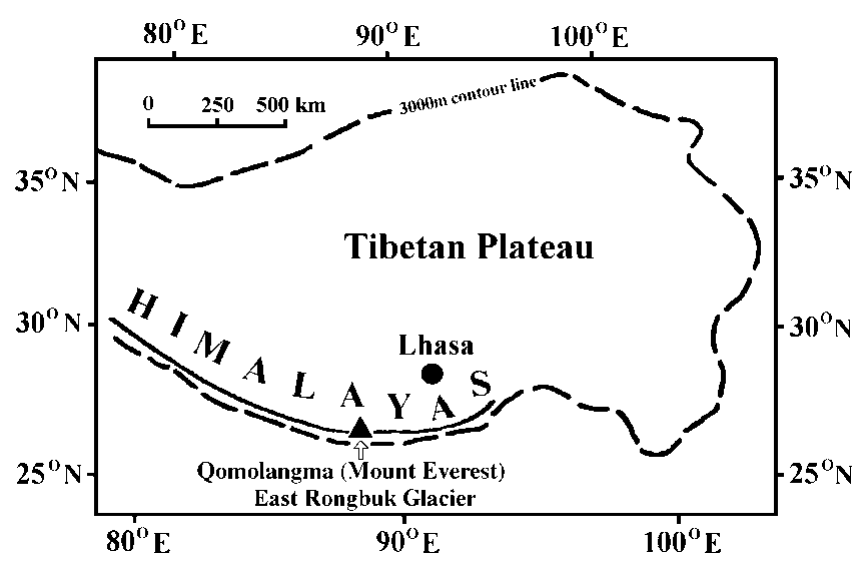

Fig. 1. Location map of ice-core drilling site.
$>8000$ years if adopting the GISP2 $\delta^{18} \mathrm{O}_{\text {atm }}$ time-scale. However, an $80.4 \mathrm{~m}$ annually dated ice core recovered from the same East Rongbuk Glacier has a maximum age of 154 years (Kang and others, 2002; Qin and others, 2002). This excludes any possibility of early-Holocene origin for the bottom ice of our cores.

Both methane profiles show a rapid increase during the industrial period and low methane concentrations (a little below 700 ppbv pre-industrial methane level) in the very bottom sections, but these values are still much higher than the methane concentrations during the middle Holocene ( $\sim 570 \mathrm{ppbv}$ ) as depicted by the Greenland Ice Core Project (GRIP) ice core (Fig. 2), even after taking into account the interpolar methane gradient (35 ppbv for the period 2501000 years BP: Chappellaz and others, 1997b; Houweling and others, 2000). This further indicates the age of the bottom ice to be late Holocene.

To estimate precisely the age of the bottom ice, we prepared a $\mathrm{CH}_{4} / \delta^{18} \mathrm{O}_{\text {atm }}$ phase plane by using the GRIP $\mathrm{CH}_{4}$ and GISP2 $\delta^{18} \mathrm{O}_{\text {atm }}$ records, then superimposed our $\mathrm{CH}_{4}$ and $\delta^{18} \mathrm{O}_{\text {atm }}$ pairs (Fig. 3). All the $\mathrm{CH}_{4}$ and $\delta^{18} \mathrm{O}_{\text {atm pairs }}$ from the bottom $2 \mathrm{~m}$ of our cores are situated within BOX 1 (in Fig. 3). The ages of the $\mathrm{CH}_{4}$ and $\delta^{18} \mathrm{O}_{\text {atm }}$ pairs of the GRIP and GISP2 ice cores within BOX 1 are in the range 1498-2055 years BP, confirming the late-Holocene origin of the bottom ice. Furthermore, we exclude any possibility of connecting the $\mathrm{CH}_{4} / \delta^{18} \mathrm{O}_{\text {atm }}$ pairs within BOX 1 to the early Holocene. Otherwise, some of the $\mathrm{CH}_{4} / \delta^{18} \mathrm{O}_{\text {atm }}$ pairs within BOX 2 (in Fig. 3; from shallower sections, thus younger than those in BOX 1) would be dated at middle Holocene (Fig. 3), a period that is beyond any possible connection to BOX 2, even after considering the cumulative
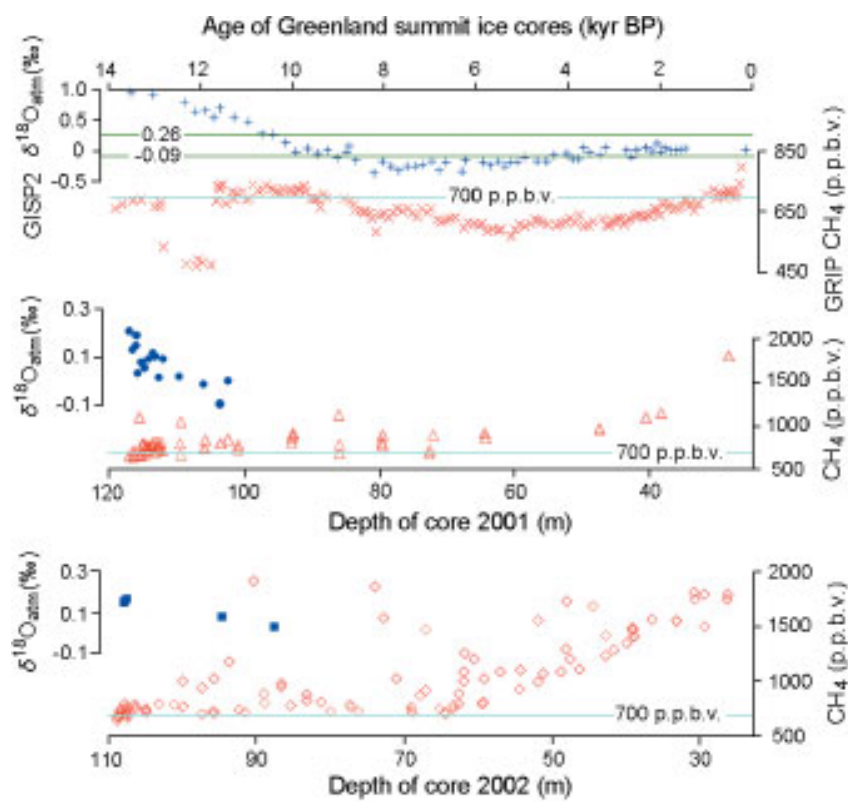

Fig. 2. Ice-core methane and $\delta^{18} \mathrm{O}_{\mathrm{atm}}$ profiles of the GRIP, GISP2, Himalayan core 2001 and core 2002. All the methane results are on the LGGE-University of Bern internal scale (Chappellaz and others, 1997b), which excludes the experimental bias for comparison. The 700 ppbo pre-industrial $\mathrm{CH}_{4}$ level depicted by polar ice cores is added for clarity. The $-0.09 \%$ and $0.26 \% \delta^{18} \mathrm{O}_{\text {atm }}$ horizons of the summit core panel are the minimum and maximum of the Himalayan ice cores, respectively. 


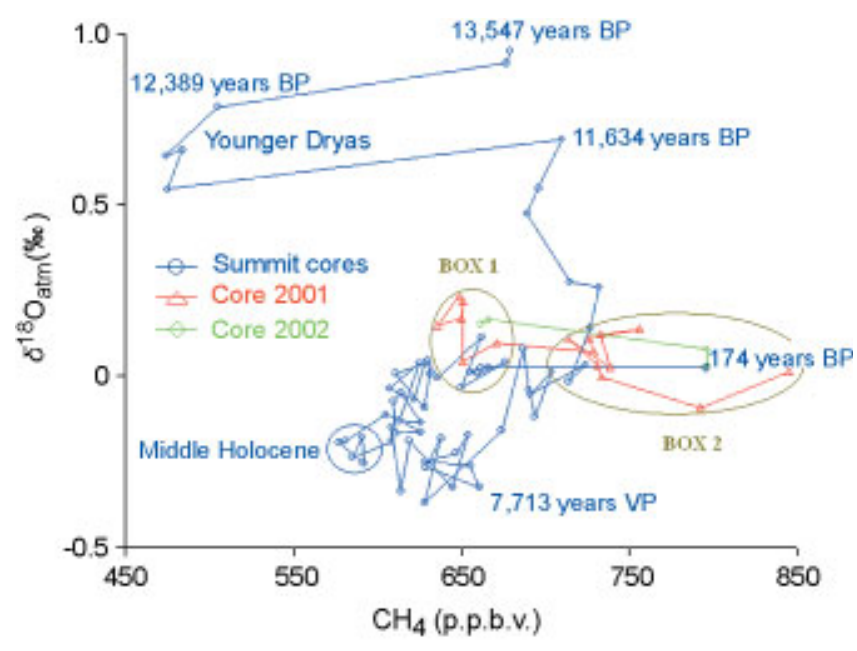

Fig. 3. The $\mathrm{CH}_{4} / \delta^{18} \mathrm{O}_{\mathrm{atm}}$ pairs of the Himalayan ice cores superposed on the GRIP-GISP2 $\mathrm{CH}_{4} / \delta^{18} \mathrm{O}_{\text {atm }}$ phase plane. The ages are GISP2 time-scale (Meese and others, 1994) after correction of gas-ice time difference, and the GISP2GRIP chronologies are in good agreement back to 3300 years BP (Southon, 2002), avoiding bias for our dating due to its younger age.

effects of the experimental uncertainty (Chappellaz and others, 1997a; Landais and others, 2003) and the methane interpolar gradient (Chappellaz and others, 1997b; Houweling and others, 2000). The ice-core base is dated at $\sim 1650$ years BP when applying a simple flow model. Thus our ice cores will provide extremely high-resolution paleoclimate records for the Himalayan region.

\section{ACKNOWLEDGEMENTS}

Thanks are due to S. Kang and many other scientists, technicians, graduates and porters for hard work expertly carried out in the field. Special thanks are extended to B. Bellier and S. Cherrier for chemical measurement, and to M. Bender for the GISP2 $\delta^{18} \mathrm{O}_{\text {atm }}$ data. This work was supported by the Chinese Academy of Sciences (100 Talents Project and KZCX1-10-02), the Natural Science Foundation of China (90411003), the Centre National de la Recherche Scientifique, France, and the U.S. National Science Foundation (ATM 0139491).
Laboratory of Ice Core and Cold Regions Environment,

HOU SHUGUI QIN DAHE

Cold and Arid Regions Environmental and Engineering Research Institute,

Chinese Academy of Sciences,

Lanzhou 730000, China

E-mail:shugui@ns.lzb.ac.cn

IPSL/Laboratoire des Sciences

JEAN JOUZEL du Climat et de

l'Environnement,

VALÉRIE MASSON-DELMOTTE

CEA/CNRS,

91191 Gif-sur-Yvette, France

ULRICH VON GRAFENSTEIN

AMAELLE LANDAIS

NICOLAS GAILLON

Laboratoire de Glaciologie et

Géophysique de l'Environnement

JÉRÔME CHAPPELLAZ

du CNRS,

54 rue Molière, BP96,

38402 Saint-Martin-d'Hères Cedex, France

28 October 2003

\section{REFERENGES}

Chappellaz, J., E. Brook, T. Blunier and B. Malaizé. 1997a. $\mathrm{CH}_{4}$ and $\delta^{18} \mathrm{O}$ of $\mathrm{O}_{2}$ records from Antarctic and Greenland ice: a clue for stratigraphic disturbance in the bottom of the Greenland Ice Core Project and the Greenland Ice Sheet Project 2 ice cores. 7. Geophys. Res., 102(C12), 26,547-26,557.

Chappellaz, J. and 7 others. 1997b. Changes in the atmospheric $\mathrm{CH}_{4}$ gradient between Greenland and Antarctica during the Holocene. 7. Geophys. Res., 102(D13), 15,987-15,997.

Houweling, S., F. Dentener and J. Lelieveld. 2000. Simulation of preindustrial atmospheric methane to constrain source strength of natural wetlands. F. Geophys. Res., 105(D13), 17,243-17,255.

Kang, S. and 6 others. 2002. Twentieth century increase of atmospheric ammonia recorded in Mt. Everest ice core. 7. Geophys. Res., 107(D21). (10.1029/2001JD001413.)

Landais, A. and 12 others. 2003. A tentative reconstruction of the last interglacial and glacial inception in Greenland, based on new gas measurements in the GRIP ice core. F. Geophys. Res., 108(D18). (10.1029/ 2002JD003147.)

Meese, D. A. and 8 others. 1994. The accumulation record from the GISP2 core as an indicator of climate change throughout the Holocene. Science, 266(5191), 1680-1682.

Qin, D. and 6 others. 2002. Preliminary results from the chemical records of an $80.4 \mathrm{~m}$ ice core recovered from East Rongbuk Glacier, Qomolangma (Mount Everest), Himalaya. Ann. Glaciol., 35, 278-284.

Southon, J. 2002. A first step to reconciling the GRIP and GISP2 ice-core chronologies, 0-14500 yr BP. Quat. Res., 57(1), 32-37. 